\begin{tabular}{|c|c|c|}
\hline 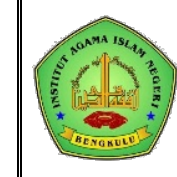 & $\begin{array}{l}\text { Al Fitrah } \\
\text { Journal Of Early Childhood Islamic Education } \\
\text { ISSN : } 2599-2287 \\
\text { Vol.1 No.2 Januari } 2018\end{array}$ & $\begin{array}{r}\text { Pemerolehan Bahasa Pada Anak Usia 3-4 } \\
\text { Tahun...... } \\
\text { Wenny Aulia Sari }\end{array}$ \\
\hline
\end{tabular}

\title{
PEMEROLEHAN BAHASA PADA ANAK USIA 3-4 TAHUN (DITINJAU DARI PEMEROLEHAN SEMANTIK YANG DIKUASAI ANAK USIA 3-4 TAHUN) DENGAN MENGGUNAKAN MEDIA GAMBAR
}

\begin{abstract}
Abstrak
Tujuan penelitian ini adalah untuk untuk mendeskripsikan pemerolehan bahasa anak usia 3-4 tahun ditinjau dari pemerolehan semantik ketika media gambar diperlihatkan dan saat menggeneralisasikan gambar-gambar (terhadap respon).Subjek pada penelitian ini adalah seorang anak perempuan yang berusia 3 tahun yang bernama Faradila Diwanta yang biasa dipanggil dengan "Fara". Analisis data dalam penelitian ini dilaksanakan dengan membandingkan setiap data atau respon yang didapat terhadap anak usia 3;0-4;0 tahun, menginterpretasikannya sesuai data yang ada dan memberi kesimpulan berdasarkan analisi data tersebut.Pemerolehan bahasa ditinjau dari fitur-fitur semantik dengan media gambar ini dapat membuat anak memperoleh bahasa dan dengan adanya stimulus-respon dapat membuat perkembangan psikologi anak menjadi berkembang serta Respon pada saat menggeneralisasikan gambar-gambar dapat membuat pemahaman anak terhadap gambargambar yang diperlihatkan.
\end{abstract}

Kata kunci: Pemerolehan Bahasa, Semantik dan Media Gambar

\section{Pendahuluan}

Proses

pemerolehan

dan

penguasaan bahasa kanak-kanak merupakan satu perkara yang tidak jelas dan cukup menakjubkan bagi para penyelidik dalam bidang linguisitk. Bagaimana manusia memperoleh bahasa merupakan satu isu yang amat mengagumkan dan sukar dibuktikan.Isu globalisasi saat ini menuntut sumber daya manusia yang berkualitas dan mampu berkomunikasi dalam berbagai bahasa . Keahlian berbahasa ini diperlukan untuk menguasai ilmu pengetahuan, memiliki pergaulan luas dan karir yang baik.

Proses anak mulai mengenal komunikasi dengan lingkungannya secara verbal disebut dengan pemerolehan bahasa anak. Pemerolehan bahasa pertama (Bl) (anak) terjadi bila anak yang sejak semula tanpa bahasa kini telah memperoleh satu bahasa. Pada masa pemerolehan bahasa anak, anak lebih mengarah pada fungsi komunikasi daripada bentuk bahasanya. Pemerolehan bahasa anak-anak dapat dikatakan mempunyai ciri kesinambungan, 


\begin{tabular}{|c|c|c|}
\hline 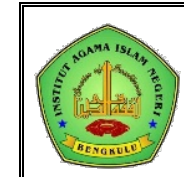 & $\begin{array}{l}\text { A1 Fitrah } \\
\text { Journal Of Early Childhood Islamic Education } \\
\text { ISSN : } 2599-2287 \\
\text { Vol.1 No.2 Januari } 2018\end{array}$ & $\begin{array}{r}\text { Pemerolehan Bahasa Pada Anak Usia 3-4 } \\
\text { Tahun...... } \\
\text { Wenny Aulia Sari }\end{array}$ \\
\hline
\end{tabular}

memiliki suatu rangkaian kesatuan, yang bergerak dari ucapan satu kata sederhana menuju gabungan kata yang lebih rumit.

Menurut Chaer pemerolehan bahasa atau akuisisi bahasa adalah proses yang berlangsung di dalam otak seseorang kanak-kanak ketika dia memperoleh bahasa pertamanya atau ibunya. Ada dua proses yang terjadi ketika seseorang kanakkanak sedang memperoleh bahasa pertamanya yaitu proses kompetensi dan proses performansi ${ }^{1}$. Sejalan dengan teori Chomsky dalam Chaer, menyatakan kompetensi itu menyangkup tiga buah komponen tata bahasa, yaitu komponen sintaksis, komponen semantik, dan komponen fonologi. Oleh karena itu pemerolehan bahasa dapat dibagi menjadi pemerolehan sintaksis, pemerolehan semantik, dan pemerolehan fonologi ${ }^{2}$.

\section{Menurut Marjusman Maksam,} pemerolehan bahasa itu dimulai dari pemerolehan semantik, sesudah itu baru diikuti dengan pemerolehan fonologi, dan barulah terakhir pemerolehan sintaksis. Pemerolehan semantik merupakan pemerolehan aspek bahasa yang pertama dikuasai oleh anak. Hal itu disebabkan oleh karena pada usia sangat dini anak sudah

\footnotetext{
${ }^{1}$ Chaer, Abdul. 2003. Psikolinguistik: Kajian Teoritik. Jakarta: PT Rineka Cipta. Hal. 167

${ }^{2}$ Chaer, Abdul. 2003. Psikolinguistik: Kajian Teoritik. Jakarta: PT Rineka Cipta. Hal. 168
}

mengerti dengan maksud (makna) ucapan dari orang-orang disekitarnya ${ }^{3}$.

$$
\text { Dalam penelitian terhadap }
$$
pemerolehan bahasa pada anak-anak, banyak media yang dapat kita gunakan, seperti media gambar, lagu, buku dongeng, dan media lainnya Media merupakan peralatan yang digunakan untuk membantu atau mempermudah proses pembelajaran dalam memperoleh bahasa. Salah satu media yang peneliti ambil untuk memperoleh bahasa pada anak-anak, yaitu dengan menggunakan media media gambar. Media gambar merupakan salah satu alat untuk menyampaikan informasi yang dapat merangsang anak dalam memperoleh bahasa.

Media gambar sangat sesuai dalam meneliti pemerolehan bahasa ditinjau dari segi pemerolehan semantik terhadap anakanak, karena anak-anak sangat menyukai dengan gambar-gambar. Dengan adanya media gambar ini yang kita kenalkan kepada anak-anak, maka fitur semantik anak-anak akan bertambah. Pada mulanya seorang anak hanya mengetahui dua atau tiga fitur semantik dengan adanya perkenalan media gambar terhadap anakanak ini, maka penguasaan fitur semantiknya akan bertambah.

\footnotetext{
${ }^{3}$ Maksan, Marjusman. 1993. Psikolinguistik. Padang: IKIP Padang Press. Hal. 32
} 


\begin{tabular}{|l|l|r|}
\hline & Al Fitrah & \\
Journal Of Early Childhood Islamic Education & Pemerolehan Bahasa Pada Anak Usia 3-4 \\
ISSN : 2599-2287 & Wenun..... \\
Vol.1 No.2 Januari 2018 & Wenny Aulia Sari \\
\hline
\end{tabular}

Berdasarkan hal itu, peneliti tertarik meneliti tentang pemerolehan bahasa terhadap kanak-kanak dengan menggunakan media gambar khususnya dalam pemerolehan semantik, karena sesuai dengan pendapat Marjusman Maksam pemerolehan bahasa itu dimulai dengan pemerolehan semantik. Dan untuk menguasai fitur semantik terhadap kanakkanak media gambar sangat berpengaruh sekali, karena banyak anak menyukai gambar. Penulis memilih Faradila Diwanta sebagai subjek penelitiannya. Faradila Diwanta merupakan salah satu anak yang berumur 3 tahun yang sangat menyenangi gambar.

Faradila Diwanta yang sering dipanggil dengan Fara adalah adik sepupu dari penulis. Dia dilahirkan di Bukittinggi pada tanggal 18 November 2014 di Rumah Sakit. Dia lahir dalam keadaan normal, baik dalam keadaan fisik maupun mental Faradila bukan merupakan anak kandung dari kedua orangtuanaya sekarang, melainkan anak saudara perempuan dari ayahnya sekarang. Faradila diasuh oleh orangtuanya sekarang sejak usia 3;00 bulan. Faradila tidak mempunyai adik dan kakak, ia anak satu-satunya dari keluarganya sekarang. Bahasa pertama yang diajarkan orangtuanya sekarang kepada Faradila yaitu bahasa Indonesia.
Pada usia sekarang faradila menguasai dua bahasa yaitu bahasa Indonesia dan bahasa Bengkulu. Bahasa Indonesia yang digunakan faradila jika ia berbicara dengan orangtuanya, kakak-kakak sepupunya, termasuk kepada penulis, tante-tantenya, orang-orang yang baru dikenalnya, dan keluarga lainnya. Akan tetapi Faradila menggunakan bahasa Bengkulu dengan teman-temannya yang berada di komplek rumahnya.

Nani Hendrawati merupakan ibu dari Faradila sekarang yang lahir di Nagari Kapalohilalang, Kecamatan 2X11 Enam Lingkung, Kabupaten Padang Pariaman, Sumatra Barat. Bahasa yang dipakai dalam sehari-hari adalah bahasa Minang dan Bengkulu. Pada tahun 1998, ia bersuami dan sampai sekarang ia tidak dikaruniai anak. Pada tahun 2015 ia membawa Faradila untuk dijadikan anaknya. Ayah Faradila, Dedi, lahir di Nagari Kapalohilalang, Kecamatan 2X11 Enam Lingkung, Kabupaten Padang Pariaman, Sumatra Barat. Beliau sejak dewasa berada di Yogyakarta, karena beristri beliau pindah kerja ke Sumatra Barat. Beliau bekerja sebagai wiraswasta, sedangkan istri beliau bekerja sebagai wirausaha.

Faradila tumbuh dalam keluarga kelas menengah yang untuk kebutuhan sehari-hari maupun kebutuhan lainnya 


\begin{tabular}{|c|c|c|}
\hline$\left[\begin{array}{ccc}0 \\
0 \\
x\end{array}\right.$ & $\begin{array}{l}\text { Al Fitrah } \\
\text { Journal of Early Childhood Islamic Education } \\
\text { ISSN : } 2599-2287 \\
\text { Vol.1 No.2 Januari } 2018\end{array}$ & $\begin{array}{r}\text { Pemerolehan Bahasa Pada Anak Usia 3-4 } \\
\text { Tahun...... } \\
\text { Wenny Aulia Sari }\end{array}$ \\
\hline
\end{tabular}

tercukupi. Faradila sekarang belum bersekolah. Faradila banyak memiliki gambar-gambar, seperti gambar hewan, buah-buahan, dan huruf-huruf, serta angkaanaka. Oleh karena itu, penulis ingin mengetahui pemerolehan bahasa ditinjau dari pemerolehan semantik faradila dengan menggunakan media gambar yang dimilikinya.

Berdasarkan masalah di atas, dapat dirumuskan, "Bagaimanakah pemerolehan bahasa anak usia 3-4 tahun ditinjau dari pemerolehan semantik yang dikuasai anak usia 3-4 tahun dengan menggunakan media gambar?”. Adapun tujuan dari penelitian ini adalah untuk; (1) mendeskripssikan pemerolehan bahasa anak usia 3;0-4;0 ditinjau dari pemerolehan semantik ketika media gambar diperlihatkan (terhadap respon anak)?

mendeskripsikanpemerolehan bahasa anak usia 3;0-4;0 ditinjau dari pemerolehan semantik saat menggeneralisasikan gambar-gambar (terhadap respon)?. Jenis penelitian yang akan dilaksanakanadalah penelitian kualitatif dengan menggunakan metode deskriptif. Bogdan dan Taylor dalam Moleong, menyatakan bahwa penelitian kualitatif sebagai prosedur penelitian yang menghasilkan data deskriptif yang berupa kata-kata tertulis atau lisan dari orang-orang dan perilaku yang diamati ${ }^{4}$. Oleh sebab itu, jenis penelitian kualitatif ini tepat digunakan dalam mencapai sasaran.

Metode yang digunakan dalam penelitian ini adalah meode deskripstif. Yang dimaksud dengan metode deskripstif adalah suatu metode dalam meneliti status sekelompok manusia, suatu objek, suatu set kondisi, suatu system pemikiran ataupun suatu kelas peristiwa pada masa sekarang ${ }^{5}$. Oleh sebab itu, cara yang tepat digunakan dalam mencapai sasaran sehingga dapat memahami suatu objek yang dikehendaki adalah metode deskriptif. Moh. Nazir mengatakan bahwa tujuan dari metode deskriptif ini adalah untuk membuat deskripsi, gambaran atau lukisan secara sistematis, faktual dan akurat mengenai fakta-fakta serta hubungan antarfenomena yang diselidiki.

\section{Kajian Teori}

\section{Pemerolehan Bahasa}

Pemerolehan bahasa atau akuisisi adalah proses yang berlangsung di dalam otak seseorang kanak-kanak ketika dia memperoleh bahasa pertamanya atau

\footnotetext{
${ }^{4}$ Moleong, Lexy. 2005. Metodologi Penelitian Kualitatif. Bandung: Remaja Rosdakarya Offset. Hal 5

${ }^{5}$ Nazir. 1988. Metode Penelitian. Jakarta: Ghalia Indonesia. Hal 63
} 


\begin{tabular}{|c|c|c|}
\hline & $\begin{array}{l}\text { Al Fitrah } \\
\text { Journal Of Early Childhood Islamic Education } \\
\text { ISSN : } 2599-2287 \\
\text { Vol.1 No.2 Januari } 2018\end{array}$ & $\begin{array}{r}\text { Pemerolehan Bahasa Pada Anak Usia 3-4 } \\
\text { Tahun...... } \\
\text { Wenny Aulia Sari }\end{array}$ \\
\hline
\end{tabular}

bahasa ibunya ${ }^{6}$. Pemerolehan biasanya dibedakan dari pembelajaran bahasa.

Pembelajaran bahasa berkaitan dengan proses-proses yang terjadi pada waktu seseorang kanak-kanak mempelajari bahasa kedua, setelah ia memperoleh bahasa pertamanya. Jadi pemerolehan bahasa berkenaan dengan bahasa pertama, sedangkan pembelajaran bahasa berkenaan dengan bahasa kedua. Ada dua proses yang terjadi ketika seseorang kanak-kanak sedang memperoleh bahasa pertamanya, yaitu proses kompetensi dan proses performansi. Chomsky dalam Chaer, membagi kompetensi itu mencakup tiga komponen tata bahasa, yaitu kmponen sintaksis, semanti, dan fonologi. Oleh karena itu pemerolehan bahasa itu lazim dibagi menjadi pemerolehan sintaksis, pemerolehan semantik, dan pemerolehan fonologi ${ }^{7}$.

Menurut Ruqayyah, proses anak mulai mengenal komunikasi dengan lingkungannya secara verbal disebut dengan pemerolehan bahasa anak. Pemerolehan bahasa pertama (Bl) (anak) terjadi bila anak yang sejak semula tanpa bahasa kini telah memperoleh satu

\footnotetext{
${ }^{6}$ Chaer, Abdul. 2003. Psikolinguistik: Kajian Teoritik. Jakarta: PT Rineka Cipta. Hal 167

${ }^{7}$ Chaer, Abdul. 2003. Psikolinguistik: Kajian Teoritik. Jakarta: PT Rineka Cipta. Hal 168
}

bahasa $^{8}$. Pada masa pemerolehan bahasa anak, anak lebih mengarah pada fungsi komunikasi daripada bentuk bahasanya. Pemerolehan bahasa anak-anak dapat dikatakan mempunyai ciri kesinambungan, memiliki suatu rangkaian kesatuan, yang bergerak dari ucapan satu kata sederhana menuju gabungan kata yang lebih rumit. Ada dua pengertian mengenai pemerolehan bahasa. Pertama, pemerolehan bahasa mempunyai permulaan yang mendadak, tiba-tiba. Kedua, pemerolehan bahasa memiliki suatu permulaan yang gradual yang muncul dari prestasi-prestasi motorik, sosial, dan kognitif pralinguistik.

Penelitian mengenai bahasa manusia telah menunjukkan banyak hal mengenai pemerolehan bahasa, mengenai apa yang dilakukan atau tidak dilakukan seorang anak ketika belajar atau memperoleh bahasa, Fromkin dan Rodman,dalam Ruqayyah, menyatakan bahwa
1) Anak tidak belajar bahasa dengan cara menyimpan semua kata dan kalimat dalams ebuah kamus mental raksasa. Daftar kata-kata itu terbatas,

\footnotetext{
${ }^{8}$ Ruqayah. 2009. Pemerolehan Bahasa Anak Usia 4-6 Tahun.

https://massofa.wordpress.com/2008/11/19/pemer olehan-bahasa-anak-usia-4-6-tahun/
} 


\begin{tabular}{|l|l|r|}
\hline \begin{tabular}{|l|l|} 
A1 Fitrah \\
Journal Of Early Childhood Islamic Education
\end{tabular} & $\begin{array}{r}\text { Pemerolehan Bahasa Pada Anak Usia 3-4 } \\
\text { Tahun..... } \\
\text { ISSN : 2599-2287 }\end{array}$ \\
Vol.1 No.2 Januari 2018 & Wenny Aulia Sari \\
\hline
\end{tabular}

tetapi tidak ada

kamusyang bisa

mencakup. 2) semua

kalimat yang tidak

terbatas

jumlahnya.Anak-anak

dapat belajar

menyusun kalimat,

kebanyakan berupa

kalimat yang belum

pernah mereka

hasilkan sebelumnya.

3) Anak-anak belajar

memahami kalimat

yang belum pernah

mereka dengar

sebelumnya. Mereka

tidak dapat

melakukannya dengan

menyesuaikan tuturan

yang didengar dengan

beberapa kalimat yang

ada dalam pikiran

mereka. Anak-anak

selanjutnya harus

menyusun "aturan”

yang membuat mereka

dapat menggunakan

bahasa secara kreatif.

Tidak ada yang

mengajarkan aturan

ini. Orang tua tidak

lebih menyadari aturan fonologis, morfologis, sintaktis, dan semantik daripada ${ }^{9}$.

\footnotetext{
${ }^{9}$ Ruqayah. 2009. Pemerolehan Bahasa Anak Usia 4-6 Tahun.

https://massofa.wordpress.com/2008/11/19/pemer olehan-bahasa-anak-usia-4-6-tahun/
}

Menurut Chear pemerolehan bahasa anak, dapat dibagi atas beberapa hipotesis, yaitu.

\section{Hipotesis Nuranai}

Manusia lahir dengan dilengkapi oleh suatu alat yang memungkinkan dapat berbahasa dengan mudah dan cepat. Hipotesi nurani ini dapat dibedakan menjadi, (a) hipotesis nurani bahasa, merupakan satu asumsi yang menyatakan bahwa sebagian atau semua bagian dari bahasa tidaklah dipelajari atau diperoleh tetapi ditentukan oleh fitur-fitur nurani yang khusus dari organisme manusia, (b) hipotesia nurani mekanisme, menyatakan bahwa proses pemerolehan bahasa oleh manusia ditentukan oleh perkembangan kognitif umum dan mekanisme nurani umum yang berinteraksi dengan pengalaman.

Mengenai hipotesis nurani bahasa, Chomsky dan Miller mengatakan adanya alat khusus yang dimiliki setiap kanakkanak sejak lahir untuk dapat berbahasa yang bernama (LAD) Language Acquisition Device yang berfungsi untuk memungkinkan seorang kanak-kanak memperoleh bahasa ibunya.

\section{Hipotesis Tabularasa}

Menyatakan bahwa otak bayi pada waktu dilahirkan sama seperti kertas 


\begin{tabular}{|c|c|c|}
\hline restomive & $\begin{array}{l}\text { A1 Fitrah } \\
\text { Journal Of Early Childhood Islamic Education } \\
\text { ISSN : } 2599-2287 \\
\text { Vol.1 No.2 Januari } 2018\end{array}$ & $\begin{array}{r}\text { Pemerolehan Bahasa Pada Anak Usia 3-4 } \\
\text { Tahun...... } \\
\text { Wenny Aulia Sari }\end{array}$ \\
\hline
\end{tabular}

kosong, yang nanti akan ditulis atau diisi dengan pengalaman-pengalaman. Menurut hipotesis tabularasa, semua pengetahuan dalam bahasa manusia yang tampak dalam perilaku berbahasa adalah merupakan hasil dari intergrasi peristiwa-peristiwa linguistic yang dialami dan diamati oleh manusia itu.

\section{Hipotesis Kesemestaan Kognitif}

Menurut teori yang didasarkan pada kesempatan kognitif, bahasa diperoleh berdaarkan struktur-struktur kognitif deriamotor. Struktur-struktur ini diperoleh kanak-kanak melalui interaksi dengan benda-benda atau orang-orang di sekitarnya $^{10}$.

\section{Pemerolehan Semantik}

Menurut Marjusman Maksan, pemerolehan semantik merupakan pemerolehan aspek bahasa yang pertama dikuasai anak. Hal itu disebabkan karena pada usia yang sangat dini anak sudah mengerti dengan maksud (makna) ucapan dari orang-orang di sekitarnya. Tetapi, alatalat ucap anak itu masih belum lagi berfungsi mennurut seharusnya, karena

\footnotetext{
${ }^{10}$ Chaer, Abdul. 2003. Psikolinguistik: Kajian Teoritik. Jakarta: PT Rineka Cipta. Hal 168-178
}

masih dalam proses pertumbuhan ${ }^{11}$. Karena itu, apa yang sudah diketahuinya maknanya itu, belum lagi mampu diucapkannya.

Menurut Baret, dalam Dardjowidjodo, anak barat umumnya mulai memakai kata pada umur 1;0. sekitar umur 1;7 anak telah memperoleh 50 kata dan mulai umur 1;8 anak makin cepat pemerolehan katanya. Pada umur 2;0 anak dipekirakan telah menguasai 200-300 kata $^{12}$. Kata-kata yang akan diperoleh anak ditentukan oleh lingkungannya. Misalnya anak yang dididik oleh orang yang mampu dan tinggal di kota, kata-kata yang dikuasai anak yaitu bola, anjing kucing, apel, sepatu, beruang, dsb. Sedangkan anak yang dididik dengan orang desa yang kurang mampu kosa kata yang dikuasai anak yaitu bebek, sapi, rumput, daun, dsb. Hal ini disebabkan, anak yang berada di kota banyak memiliki buku gambar, bermacammacam mainan, rumahnya terdapat alatalat elektronik, orangtuanya juga mempunyai waktu untuk bergaul banyak dengan anaknya, maka anak-anak akan memperoleh kata-kata seperti itu. Sedangkan pada anak petani apalagi berada

\footnotetext{
${ }^{11}$ Maksan, Marjusman. 1993. Psikolinguistik.

Padang: IKIP Padang Press. Hal 32

${ }^{12}$ Darjhowidjodjo, Soenjono. 2003. Psikolinguistik:

Pengantar Pemahaman Bahasa Manusia.

Jakarta:Yayasan Obor Indonesia. Hal 258
} 
di desa terpencil kata-kata seperti yang dikuasai anak kota minim untuk dikuasai.

Menurut Chaer, pada tahun pertama dalam kehidupannya seorang bayi menghabiskan waktunya untuk mengamati dan mengumpulkan sebanyak-banyaknya informasi yang ada di sekitar kehidupannya. Pengamatan ini dilakukan melalui seluruh panca inderanya ${ }^{13}$. Apa yang diamati dan dikumpulkan itu menjadi ”pengetahuan dunianya”. Berdasarkan pengetahuan dunianya inilah si bayi memperoleh semantik bahasa dunianya dengan cara melekatkan “makna” yang tetap kepada urutan bunyi bahasa tertentu $^{14}$. Dalam perkembangan psikolinguistik ada tiga teori mengenai pemerolehan semantik, yaitu.

\section{Teori Hipotesis Fitur Semantik}

Kanak-kanak memperoleh makna suatu kata dengan cara menguasai fitur-fitur semantik kata itu satu demi satu sampai semua fitur semantik itu dikuasai, seperti yang dikuasai oleh orang dewasa. Asumsi-asumsi yang menjadi dasar hipotesis fitur-fitur semantik adalah: a) fitur-fitur makna yang digunakan kanak-kanak dianggap sama dengan beberapa fitur makna yang digunakan oleh orang dewasa.

b) Karena pengalaman kanakkanak mengenai dunia ini dan mengenai bahasa masi sangat terbatas bila dibandingkan dengan pengalaman orang dewasa, maka kanak-kanak hanya akan menggunakan dua atau tiga fitur makna saja untuk sebuah kata sebagai masukan leksikon.

c) Karena pemilihan fitur-fitur yang berkaitan ini didasarkan pada pengalaman kanak-kanak sebelumnya, maka fitur-fitur ini pada umumnya didasarkan pada informasi persepsi atau pengamatan.

\footnotetext{
${ }^{13}$ Chaer, Abdul. 2003. Psikolinguistik: Kajian Teoritik. Jakarta: PT Rineka Cipta. Hal 194

${ }^{14}$ Chaer, Abdul. 2003. Psikolinguistik: Kajian Teoritik. Jakarta: PT Rineka Cipta. Hal 195
} 


\begin{tabular}{|l|l|r|}
\hline & Al Fitrah & \\
Journal Of Early Childhood Islamic Education & Pemerolehan Bahasa Pada Anak Usia 3-4 \\
ISSN : 2599-2287 & Wenun..... \\
Vol.1 No.2 Januari 2018 & Wenny Aulia Sari \\
\hline
\end{tabular}

2. Teori Hipotesis Hubungan-Hubungan Gramatikal

Menurut Mc. Neil pada waktu dilahirkan kanak-kanak telah dilengkapi dengan hubungan-hubungan gramatikal dalam yang nurani. Oleh karena itu, kanakkanak pada awal proses pemerolehan bahasanya telah berusaha membentuk satu “kamus makna kalimat”. Yaitu setiap butir leksikal dicantumkan dengan semua hubungan gramatikal yang digunakan secara lengkap pada tahapholofrasis. Penyesuaian kamus makna kata ini merupakan perkembangan kosakata kanakkanak yang dilakukan secara horizontal, artinya pada mulanya kanak-kanak hanya memasukan beberapa fitur semantik untuk setiap butir leksikal ke dalam kamusnya atau secara vertikal, artinya kanak-kanak secara serentak memasukkan semua fitur semantik sebuah ke dalam kamusnya.

\section{Teori Hipotesis Generalisasi}

Yaitu kemampuan kanak-kanak melihat hubungan-hubungan semantik antara nama-nama benda (kata-kata) mulai dari yang konkret sampai pada yang abstrak.

\section{Teori Hipotesis Primitive-Primitif}

\section{Universal}

Semua bahasa yang ada di dunia ini dilandasi oleh satu perangkat primitifprimitif semantik universal dan rumus- rumus untuk menggabungkan primitifprimitif semantik ini dengan butir-butir leksikal.

Menurut Clakr dalam Chaer, perkembangan pemerolehan semantik ada empat tahap, yaitu ${ }^{15}$.

1. Tahap Penyimpatan Makna $(1 ; 0-1 ; 6)$ Pada tahap ini kanak-kanak menganggap satu benda tertentu yang dicakup[ satu makna menjadi nama dari benda itu. Jadi yang disebut denngan \{gukguk\} hanyalah anjing yang ada di rumahnya saja, termasuk yang berada di luar rumah si anak.

2. Tahap Generalisasi Berlebihan (1;6 $2 ; 6)$

Pada tahap ini kanak-kanak mulai menggeneralisasikan makna suatu kata secara berlebihan. Jadi, yang dimaksud dengan anjing atau gukguk adalah semua binatang yang berkaki empat, termasuk kambing dan sapi.

3. Tahap Medan Semantik $(2 ; 6-5 ; 0)$

Pada tahap ini kanak-kanak mulai mengelompokkan kata-kata yang berkaitan ke dalam satu medan semantik.

4. Tahap Generalisasi $(5 ; 0-7 ; 0)$

\footnotetext{
${ }^{15}$ Chaer, Abdul. 2003. Psikolinguistik: Kajian Teoritik. Jakarta: PT Rineka Cipta. Hal 196
} 


\begin{tabular}{|c|c|c|}
\hline$\left[\begin{array}{ccc}0 \\
0 \\
x\end{array}\right.$ & $\begin{array}{l}\text { Al Fitrah } \\
\text { Journal of Early Childhood Islamic Education } \\
\text { ISSN : } 2599-2287 \\
\text { Vol.1 No.2 Januari } 2018\end{array}$ & $\begin{array}{r}\text { Pemerolehan Bahasa Pada Anak Usia 3-4 } \\
\text { Tahun...... } \\
\text { Wenny Aulia Sari }\end{array}$ \\
\hline
\end{tabular}

Pada tahap ini kank-kanak telah mulai mampu mengenal benda-benda yang sama dari sudut persepsi, bahwa benda-benda itu mempunyai fitur-fitur semantik yang sama.

\section{Stimulus - Respons}

Menurut Dimyati dan Mudjiono dalam Tressyalina, menerangklan bahwa perubahan tingkah laku seseorang anak dalam hal kemampuannya untuk bertingkah laku dengan cara baru merupakan hasil interaksi antara stimulus dan respon ${ }^{16}$. Dalam teori pembelajaran ada dua kelompok besar, yaitu (1) teori stimulus-respon dari psikologi behavirisme, dan (2) teori psikologi kognitifisme ${ }^{17}$.

Disebut teori stimulus-respon karena teori ini memiliki dasar pandangan bahwa perilaku itu, termasuk perilaku berbahasa, bermula dengan adanya stimulus (rangsangan, aksi) yang segera menimbulkan respon, (reaksi, gerak balas) teori ini terdiri dari, yaitu;

\section{Teori Pembiasan Klasik Dari Pavlov}

\footnotetext{
${ }^{16}$ Tressyalina. 2007. Respon Verbal dan Nonverbal Anak Usia Prasekolah (Tesis). Padang: UNP. Hal 8

${ }^{17}$ Chaer, Abdul. 2003. Psikolinguistik: Kajian

Teoritik. Jakarta: PT Rineka Cipta. Hal 83
}

Menurut teori ini kemampuan seseorang untuk membentuk respons-respons yang dibiasakan berhubungan erat dengan jenis system yang digunakan.

2. Teori Penghubungan dari Thorndike

Teori ini memiliki tiga prinsip, yaitu; (a) Jika suatu organisme bersedia melakukan suatu tindakan, maka menyelesaikan suatu perbuatan itu akan menimbulkan kepuasan hati, (2) Jika satu urutan rangsangan (stimulus) - gerak balas (respons) diikuti oleh satu keadaan yang memuaskan hati; maka hubungan S-R itu akan diperkuat; sementara pengganggu akan menghentikan pengulangan hubungan itu, (3) Hubunganhubungan S-R dapat diperkuat melalui latihan-latihan.

3. Teori Behaviorisme dari Watson Semua perilaku, menurut behaviorisme, termasuk tindak balas (respons) ditimbulkan oleh adanya rangsangan (stimulus). Jadi, jika gerak balas telah diamati dan diketahui, maka rangsangan pun dapatlah diprediksikan. Begitu juga dengan rangsangan telah diamati 


\begin{tabular}{|l|l|r|}
\hline & Al Fitrah & \\
Journal Of Early Childhood Islamic Education & Pemerolehan Bahasa Pada Anak Usia 3-4 \\
ISSN : 2599-2287 & Wenun..... \\
Vol.1 No.2 Januari 2018 & Wenny Aulia Sari \\
\hline
\end{tabular}

dan diketahui, maka gerak balas pun dapat diprediksikan.

4. Teori Kesegaran dari Guthrie

Kesegaran hubungan diantara satu gabungan stimulus-respons akan memperbesar kemungkinan berulangnya pola pasangan stimulus-respon ini. Terjadinya respons yang segera dari suatu gabungan stimulus-respons merupakan pembelajaran itu sendiri.

5. Teori Pembiasan Operan dari Skinner

Menurut Skiner yang paling penting yang harus diperhatikan hubungan antara stimulus-respon yang langsung diamati, jangan memikirkan hubungan mental di antara keduanya karena hubungan mental itu tidak dapat diamati.

6. Teori Pengurangan Dorongan dari Hull

Yang paling penting dalam teori ini adalah peningkatannya sedikit kea rah penerimaan yakni adanya sesuatu yang menengahi di antara rangsangan (stimulus) dan gerak bebas (respons) yaitu dorongan atau ketegangan yang ditimbulkan karena tercapainya suatu tujuan tertentu.

7. Teori Mediasi dari Osgood

Mengakui adanya factor mediasi atau penegah di antara rangsangan (stimulus) dan gerak balas (respon).

8. Teori Faktor dari Mouwer

Menurut Mouwer hanya perasaan (emosi) saja yang dapat dibiasakan, sedangkan perilakutidak dapat. Jadi, setiap respon yang dilazimkan adalah merupakan satu respon emosi yang bertindak sebagai satu dorongan yang merangsang seseorang untuk bertindak ${ }^{18}$.

\section{Media Gambar}

Pada hakikatnya media telah memperluas atau memperpanjang kemampuan manusia untuk merasakan sesuatu (mendengar, mencium, melihat, melihat dan sebagainya). Media ini merupakan peralatan yang digunakan untuk membantu atau mempermudah proses pembelajaran khususnya pemerolehan bahasa pada anak. Setiap media adalah sarana untuk menuju suatu tujuan. Di dalam media terkandung

\footnotetext{
${ }^{18}$ Chaer, Abdul. 2003. Psikolinguistik: Kajian Teoritik. Jakarta: PT Rineka Cipta. Hal 84
} 


\begin{tabular}{|c|c|c|}
\hline$\Leftrightarrow$ & $\begin{array}{l}\text { Al Fitrah } \\
\text { Journal Of Early Childhood Islamic Education } \\
\text { ISSN : } 2599-2287 \\
\text { Vol.1 No.2 Januari } 2018\end{array}$ & $\begin{array}{r}\text { Pemerolehan Bahasa Pada Anak Usia 3-4 } \\
\text { Tahun...... } \\
\text { Wenny Aulia Sari }\end{array}$ \\
\hline
\end{tabular}

informasi yang dapat dikomunikasikan kepada orang lain. Informasi ini dapat diperoleh dalam buku, rekaman, peta, gambar, film dan sebagainya.

Anak dapat dipancing memperoleh bahasa khususnya pemerolehan semantik melalui stimulus gambar. Misalnya, orang dewasa mempersiapkan gambar benda tetentu, seperti binatang, buah-buahan, tumbuh-tumbuhan, dan sebagainya. Gambar merupakan tiruan barang (rang, binatang, tumbuh-tumbuhan, dan sebagainya) yang dibuat dengan coretan pensil pada kertas ${ }^{19}$ (KBBI, 2001:329). Gambar adalah salah satu media yang dapat digunakan untuk memperoleh bahasa pada anak khususnya dalam pemerolehan semantik.

\section{Hasil Penelitian}

\section{Analisis Data}

Data-data yang dianalisa peneliti ada dua macam, yaitu; (1) Respon Faradila ketika melihat gambar-gambar, (2) Respon Faradila saat menggeneralisasikan gambargambar.

\footnotetext{
${ }^{19}$ Departemen Pendidikan dan Kebudayaan, Kamus Besar Bahasa Indonesia, (Jakarta : Depdikbud, 2001), hal. 329.
}

1. Respon Faradila ketika Melihat Gambar-Gambar

Pada respon ini, fara menunjukkan pemerolehan bahasanya dengan psikologi perkembangan rasa ingin tahu, imajinasi, mempertahankan pendapat. 


\begin{tabular}{|c|c|c|}
\hline & $\begin{array}{l}\text { Al Fitrah } \\
\text { Journal Of Early Childhood Islamic Education } \\
\text { ISSN : } 2599-2287 \\
\text { Vol.1 No.2 Januari } 2018\end{array}$ & $\begin{array}{r}\text { Pemerolehan Bahasa Pada Anak Usia 3-4 } \\
\text { Tahun...... } \\
\text { Wenny Aulia Sari }\end{array}$ \\
\hline
\end{tabular}

Tabel 1

Respon Fara ketika melihat gambar

\begin{tabular}{|c|c|c|c|}
\hline No & Stimulus & Respon & $\begin{array}{c}\text { Psikologi } \\
\text { perkembangan }\end{array}$ \\
\hline 1. & $\begin{array}{l}\text { ala! Wewen punya banyak } \\
\text { gambar. (sambiil } \\
\text { mengeluarkan kartu } \\
\text { gambar) } \\
\text { Ini gambarnya. Ayo }\end{array}$ & $\begin{array}{l}\text { Gambar apa yang wewen } \\
\text { bawak, lihat dong. } \\
\text { Gambar apaan sih wewen. } \\
\text { Oh gambar buah. }\end{array}$ & $\begin{array}{l}\text { Rasa ingin tahu } \\
\text { Penasaran }\end{array}$ \\
\hline 2. & $\begin{array}{l}\text { gambar apa ni namanya. } \\
\text { Ini gambar apa namanya? } \\
\text { (memperlihatkan gambar }\end{array}$ & $\begin{array}{l}\text { Ih...banyak kali Wewen } \\
\text { bawak gambar. }\end{array}$ & Merasa senang \\
\hline 3. & $\begin{array}{l}\text { buah durian) } \\
\text { Kalau gambar ini apa? } \\
\text { (melihatkan gambar } \\
\text { anggur) }\end{array}$ & $\begin{array}{l}\text { Durian. Pernah suka } \\
\text { makan ini. }\end{array}$ & $\begin{array}{l}\text { Reaksi dalam bentuk } \\
\text { rasa }\end{array}$ \\
\hline 4. & $\begin{array}{l}\text { Ini apa namanya? } \\
\text { (melihatkan gambar } \\
\text { ayam) }\end{array}$ & $\begin{array}{l}\text { Ini namanya anggur } \\
\text { merah wewen. Masa } \\
\text { nggak tau sih. }\end{array}$ & $\begin{array}{l}\text { Daya ingat yang luar } \\
\text { biasa }\end{array}$ \\
\hline 5. & $\begin{array}{l}\text { Nah kalau yang ini? } \\
\text { (melihatkan gambar } \\
\text { papaya) }\end{array}$ & Ya ayamlah. & Daya ingat \\
\hline 6. & $\begin{array}{l}\text { Ini namanya papaya. } \\
\text { Kalau gambar ini apa? } \\
\text { (memperlihatkan gambar }\end{array}$ & $\begin{array}{l}\text { mmmm....nggak tau, } \\
\text { gambar apa sih namanya? }\end{array}$ & $\begin{array}{l}\text { Rasa ingin tahu yang } \\
\text { kuat }\end{array}$ \\
\hline 7. & pea) & Oh...papaya. & Daya ingat \\
\hline 8. & $\begin{array}{l}\text { Ini namanya pea sayang } \\
\text { bukan tomat. }\end{array}$ & Tomat. & Daya ingat \\
\hline 9. & $\begin{array}{l}\text { Bukanlah sayang, ini } \\
\text { pealah namanya, bukan } \\
\text { tomat. } \\
\text { Kalau ini tau nggak ala }\end{array}$ & $\begin{array}{l}\text { Bukanlah wewen. Ini } \\
\text { namanya tomat merah. } \\
\text { Masa pea. }\end{array}$ & $\begin{array}{l}\text { Mempertahankan } \\
\text { pendapat }\end{array}$ \\
\hline 10. & $\begin{array}{l}\text { namanya? } \\
\text { (memperlihatkanpenguin). } \\
\text { Ini namanya penguin. }\end{array}$ & $\begin{array}{l}\text { Mirip tomat ya wewen. } \\
\text { Pea tu apa sih? }\end{array}$ & Rasa ingin tahu \\
\hline 11. & $\begin{array}{l}\text { Nah ini apa? } \\
\text { (memperlihatkan gambar } \\
\text { kelinci) }\end{array}$ & $\begin{array}{l}\text { Ini burung apa wewen? } \\
\text { Sama mirip ayam. }\end{array}$ & Rasa ingin tahu \\
\hline 12. & $\begin{array}{l}\text { Kalau ini. } \\
\text { (memperlihatkan gambar } \\
\text { kodok). }\end{array}$ & Pe...penguin. & Daya ingat \\
\hline 13. & $\begin{array}{l}\text { Kalau....(baru memegang } \\
\text { gambar strobery). }\end{array}$ & Kelinci...... & Daya ingat \\
\hline 14. & $\begin{array}{l}\text { Kalau buah ini apa Ala? } \\
\text { (memperlihatkan gambar } \\
\text { pear) }\end{array}$ & Kodok hijau. & Daya ingat \\
\hline
\end{tabular}




\begin{tabular}{|c|c|c|}
\hline & $\begin{array}{l}\text { Al Fitrah } \\
\text { Journal of Early Childhood Islamic Education } \\
\text { ISSN : } 2599-2287 \\
\text { Vol.1 No.2 Januari } 2018\end{array}$ & $\begin{array}{r}\text { Pemerolehan Bahasa Pada Anak Usia 3-4 } \\
\text { Tahun..... } \\
\text { Wenny Aulia Sari }\end{array}$ \\
\hline
\end{tabular}

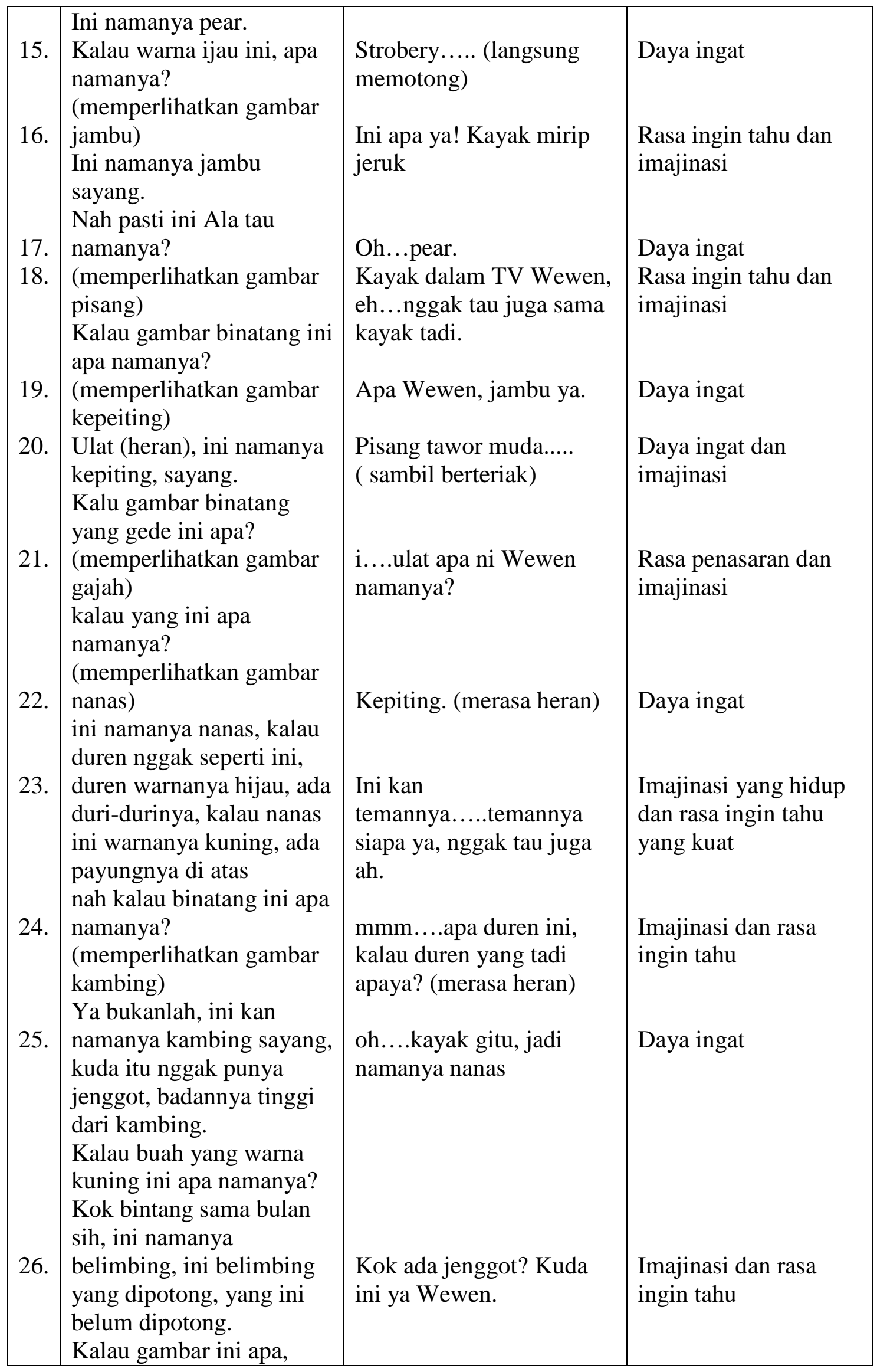




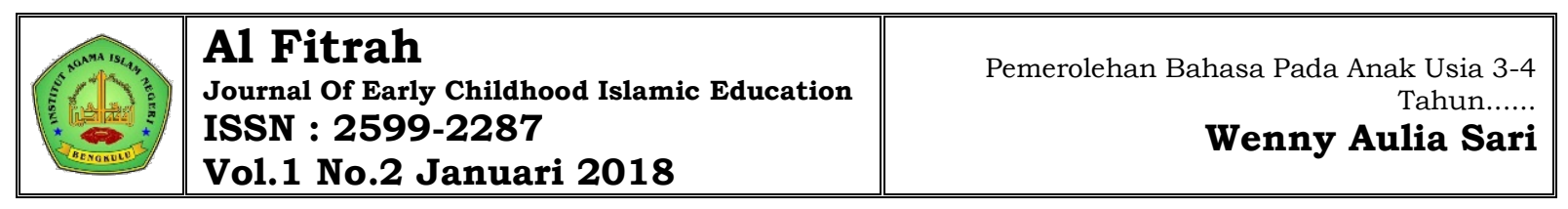

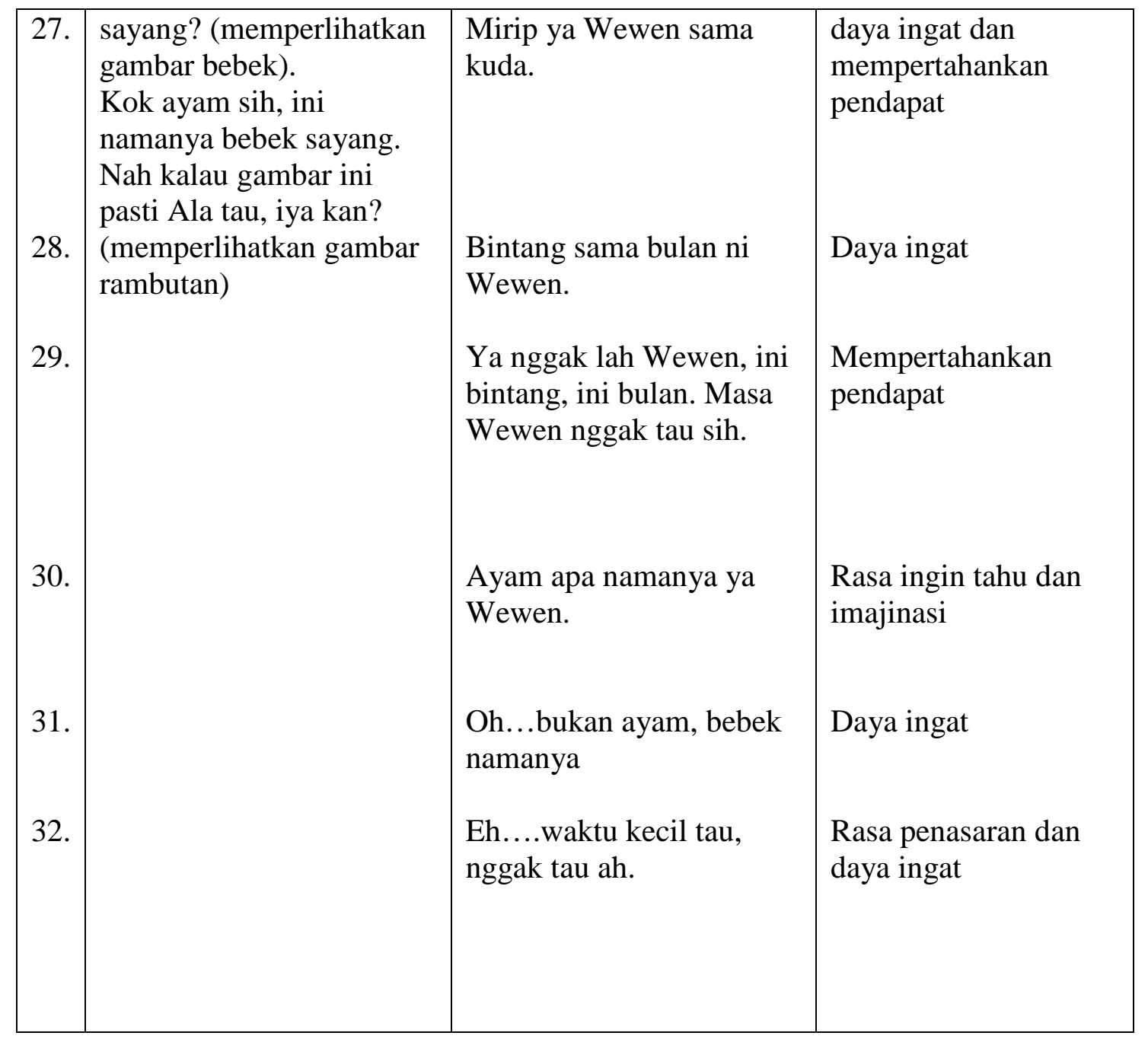

Dari tabel di atas dapat dilihat bahwa respon pertama anak merasa penasaran atau ingin tahu terhadap gambar yang akan diperlihatkan. Pada respon kedua aanak merasa senang sekali, karena gambar yang diperlihatkan menarik baginya. Pada respon ketiga anak mulai mengeluarkan reaksi terhadap rasa. Ia perrnah merasa memakan buah yang ada di gambar tersebut. Pada respon keempat anak bisa mengingat gambar apa yang diperlihatkan, karena ia memang sering memakan buah tersebut. Pada respon kelima anak mempunyai daya ingat. Ia mengingat gambar apa yang diperlihatkan. Pada respon keenam, anak tidak mengetahui gambar apa yang diperlihatkan. Ia mulai merasa penasaran dan ingin mengetahui gambar apa yang diperlihatkan. Pada respon kedelapan anak mempertahankan pendapatnya. Ia juga memberikan penjelasan tentang fitur semantik yang 


\begin{tabular}{|c|c|c|}
\hline 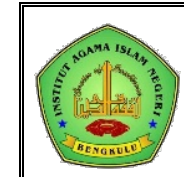 & $\begin{array}{l}\text { A1 Fitrah } \\
\text { Journal Of Early Childhood Islamic Education } \\
\text { ISSN : } 2599-2287 \\
\text { Vol.1 No.2 Januari } 2018\end{array}$ & $\begin{array}{r}\text { Pemerolehan Bahasa Pada Anak Usia 3-4 } \\
\text { Tahun...... } \\
\text { Wenny Aulia Sari }\end{array}$ \\
\hline
\end{tabular}

dikuasainya terhadap gambar itu dan pada akhirnya ia mengakui bahwa fitur semantik yang dikuasainya berbeda. Pada respon kesebelas anak ingin mengetahui gambar dengan berimajinasi. Pada respon keduabelas-kelimabelas anak sudah memiliki daya ingat. Pada respon keenambelas dan kedelapanbelas anak berimajinasi melihat gambar dan ingin mengetahui gambar apa itu. Pada respon kesembilanbelas anak mengingat gambar apa yang diperlihatkan. Pada respon keduapuluh anak telah mengingat gambar yang diperlihatkan. Pada respon keduapuluhsatu anak merasa penasaran dengan gambar dan ia berimajinasi. Begitu juga dengan respon anak keduapuluhtiga keduapuluhenam terhadap gambar, ia berimajinasi dan ingin mengetahui gambar apa yang diperlihatkan. Sedangkan respon keduapuluhtujuh anak mulai mempertahankan pendapatnya. Begitu juga dengan respon keduapuluhsembilan anak mempertahankan pendapatnya dengan mengemukankan pendapatnya. Pada respon ketigapuluh anak merasa ingin tahu dan berimajinasi. Dan pada respon ketigapuluhsatu anak merasa penasaran dan memiliki daya ingat.

\section{Respon Faradila ssaat \\ Menggeneralisasikan Gambar}

Pada respon terakhir ini, Faradila menunjukan pemerolehan bahasanya dengan psikologi perkembangan imijinasi, rasa ingin tahu , daya ingat, serta daya nalar.

Tabel 2

\section{Respon Faradila Saat Menggeneralisasikan Gambar}

\begin{tabular}{|c|c|c|c|}
\hline No. & Stimulus & Respon & $\begin{array}{c}\text { Psikologi } \\
\text { perkembangan }\end{array}$ \\
\hline 1. & $\begin{array}{l}\text { Ala, Wewen kan sudah } \\
\text { kasi tahu Ala gambar- } \\
\text { gambar ni, sekarang coba } \\
\text { Ala sebutkan lagi nama- } \\
\text { nama dari gambar yang } \\
\text { Wewen lihatkan tadi terus } \\
\text { Ala pisahkan yang mana } \\
\text { binatang dan yang mana } \\
\text { hewan. Bisa nggak Ala? }\end{array}$ & $\begin{array}{l}\text { Gimana sih maksud } \\
\text { Wewen? }\end{array}$ & Ras ingin tahu \\
\hline 2. & $\begin{array}{l}\text { Misalnya gambar stroberi } \\
\text { di tarok sebelah sini, } \\
\text { gambar kambing di tarok } \\
\text { di sebelahnya, terus } \\
\text { gambar apa lagi? }\end{array}$ & $\begin{array}{l}\text { (Rambutan), waktu } \\
\text { kecil tau, sekarang } \\
\text { nggak tau, apa tadi } \\
\text { Wewen namanya? }\end{array}$ & Rasa ingin tahu \\
\hline 3. & Rambutan namanya & Oh iya rambutan & Daya ingat \\
\hline
\end{tabular}




\begin{tabular}{|c|c|c|}
\hline$\left(\begin{array}{c}6 \\
6 \\
6\end{array}\right.$ & $\begin{array}{l}\text { Al Fitrah } \\
\text { Journal of Early Childhood Islamic Education } \\
\text { ISSN : 2599-2287 } \\
\text { Vol.1 No.2 Januari } 2018\end{array}$ & $\begin{array}{r}\text { Pemerolehan Bahasa Pada Anak Usia 3-4 } \\
\text { Tahun..... } \\
\text { Wenny Aulia Sari }\end{array}$ \\
\hline
\end{tabular}

\begin{tabular}{|c|c|c|c|}
\hline No. & Stimulus & Respon & $\begin{array}{c}\text { Psikologi } \\
\text { perkembangan }\end{array}$ \\
\hline 4. & $\begin{array}{l}\text { sayang. } \\
\text { Ayo yang mana lagi yang } \\
\text { termasuk buah dan } \\
\text { binatang. }\end{array}$ & $\begin{array}{l}\text { Ini apel masuk ke sini, } \\
\text { ini mangga masuk ke } \\
\text { sini kayak kentang } \\
\text { Wewen, ini ayam apa } \\
\text { tadi Wewen namanya? }\end{array}$ & $\begin{array}{l}\text { Daya ingat dan rasa } \\
\text { ingin tau }\end{array}$ \\
\hline 5. & $\begin{array}{l}\text { Ayo apa tadi namanya, } \\
\text { masa lupa lagi, coba ingat } \\
\text { dulu, apa namnya sayang } \\
\text { be....bek }\end{array}$ & Oh iya bebek & Daya ingat \\
\hline 6. & Yang mana lagi sayang. & $\begin{array}{l}\text { Ini nanas, ini apel, ini } \\
\text { rusa, ini kucing, ini } \\
\text { lengkeng, ini jeruk, ini } \\
\text { kelinci, ini...ini gambar } \\
\text { apa Wewen lupa Ala. }\end{array}$ & $\begin{array}{l}\text { Daya ingat dan rasa } \\
\text { ingin tahu }\end{array}$ \\
\hline 7. & $\begin{array}{l}\text { Yang mana sayang, oh ini } \\
\text { namanya babi. }\end{array}$ & $\begin{array}{l}\text { Babi...bukan Wewen } \\
\text { ini namanya tikus lihat } \\
\text { ni, tikuskan. }\end{array}$ & $\begin{array}{l}\text { Mempertahankan } \\
\text { pendapat }\end{array}$ \\
\hline 8. & $\begin{array}{l}\text { Bukanlah sayang, tikus } \\
\text { yang ini, kalau ini } \\
\text { namanya babi. }\end{array}$ & $\begin{array}{l}\text { Oh iya ya. Mirip ya } \\
\text { Wewen. }\end{array}$ & Daya ingat \\
\hline 9. & $\begin{array}{l}\text { Yao yang mana lagi yang } \\
\text { termasuk binatang sama } \\
\text { buah-buahan }\end{array}$ & $\begin{array}{l}\text { Ini buah semangka, ini } \\
\text { buah anggur, ini kodok } \\
\text { eh..kok tarok di tempat } \\
\text { buah anggur, kodok di } \\
\text { sini, ini ke...piting, ini } \\
\text { kambing bukan kuda } \\
\text { Wewen, ini baru kuda, } \\
\text { kalau ini tadi kayak } \\
\text { deren, ini ayam besar } \\
\text { ini ayam kecil, ini } \\
\text { pisang tawor muda, ini } \\
\text { baru tikus, duku, kiwi, } \\
\text { ini apa tadi, oh ya } \\
\text { jeruk, apel, nanas, } \\
\text { kelapa, ini } \\
\text { monyet...habis Wewen }\end{array}$ & Daya ingat \\
\hline
\end{tabular}

Pada tabel dua yang merupakan respon terakhir telah tampak bahwa anak menguasai/dapat menggeneralisasikan gambar-gambar serta telah menunjukan reaksi terhadap gambar. Pada respon pertama, anak kurang mengerti dengan apa yang dijelaskan sehingga ia ingin mengetahu apa maksud dari penjelasan itu. Pad respon kedua anak memiliki daya ingat dan rasa ingin tahu. Pada respon 


\begin{tabular}{|c|c|c|}
\hline 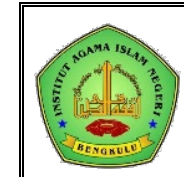 & $\begin{array}{l}\text { A1 Fitrah } \\
\text { Journal Of Early Childhood Islamic Education } \\
\text { ISSN : } 2599-2287 \\
\text { Vol.1 No.2 Januari } 2018\end{array}$ & $\begin{array}{r}\text { Pemerolehan Bahasa Pada Anak Usia 3-4 } \\
\text { Tahun...... } \\
\text { Wenny Aulia Sari }\end{array}$ \\
\hline
\end{tabular}

ketiga anak mengingat gambar apa yang telah dijelaskan tadi. Pada respon keempat anak mengingat gambar-gambar apa saja yang termasuk dalam binatang dan buahbuahan serta ingin mengetahui gambar yang mana lagi yang termasuk dalam binatang dan buah-buahan. Pada respon kelima anak mencoba meningat kembali nama-nama gambar. Pada respon keenam anak telah dapat mengenal gambargambar, akan tetapi anak juga merasa ingin tahu gambar yang tidak diketahuinya. Sedangkan pada respon ketujuh anak menunjukan pendapatnya dan mempertahankan pendapatnya. Pada respon kedelapan dan kesembilan anakanak telah menguasai nama-nama gambar serta dapat menggeneralisasikan gambargambar tersebut.

\section{Pembahasan}

Pada bagian ini, penulis membahas tentang respon-respon yang diberikan, yaitu; (1) Ketika melihat gambar. Pada tahap ini anak banyak menunjukan rasa ingin tahunya terhadap gambar-gambar itu. Anak juga telah banyak mengingat gambar-gambar apa yang diperlihatkan. Disini, anak juga menunjukan imajinasinya terhadap gambar-gambar. Dengan menunjukan media gambar seperti ini, anak banyak memperoleh bahasa, khususnya dalam fitur-fitur semantik. Di mana anak telah banyak mengetahui namanama gambar yang diperlihatkan. (2) Saat mengeneralisasikan gambar. Pada tahap ini daya ingat yang dikuasi oleh anak, rasa ingin tahupun juga masih diperlihatkan oleh anak. Begitu juga dengan mempertahankan pendapat. Dalam tahap ini anak telah mampu mengingat namanama gambar serta telah mampu mengelompokkan yang mana gambargambar yang termasuk ke dalam kelompok binatang dan ke dalam kelompok buah. Walaupun dalam tahap ini anak masih sebagian menguasai nama-nama dari gambar. Akan tetapi di sini, anak telah dapat mengeneralisasikan gambar-gambar.

\section{Kesimpulan}

Berdasrkan analisi data dan pembahasan dapat disimpulkan, sebagai berikut;

1. Respon anak ketika melihat gambar dibutuhkan suatu ransangan atau stimulus dari orang biasa agar anak dapat memperoleh bahasa dengan baik. Pemerolehan bahasa ditinjau dari fitur-fitur semantik dengan media gambar ini dapat membuat anak memperoleh bahasa dan dengan adanya stimulus-respon dapat membuat perkembangan 


\begin{tabular}{|l|l|r|}
\hline & Al Fitrah & \\
Journal Of Early Childhood Islamic Education & Pemerolehan Bahasa Pada Anak Usia 3-4 \\
ISSN : 2599-2287 & Wenun..... \\
Vol.1 No.2 Januari 2018 & Wenny Aulia Sari \\
\hline
\end{tabular}

psikologi anak menjadi

berkembang.

2. Respon

pada

saat

menggeneralisasikan gambargambar dapat membuat pemahaman anak terhadap gambargambar yang diperlihatkan. Dengan ini anak paham akan fitur-fitur semantik serta anak telah menguasai medan semantik. Di mana anak mengetahui macammacam hewan dan macam-macam buahan serta anak telah dapat membedakan yang mana hewan dan buah.

\section{Daftar Pustaka}

Chaer, Abdul. 2003. Psikolinguistik:

Kajian Teoritik. Jakarta: PT Rineka Cipta.
Darjhowidjodjo, Soenjono. 2003. Psikolinguistik: Pengantar Pemahaman Bahasa Manusia. Jakarta:Yayasan Obor Indonesia.

Alwi, Hasan dkk. 2001. Kamus Besar Bahasa Indonesia (KBBI) Edisi Ketiga. Jakarta: Balai Pustaka.

Maksan, Marjusman. 1993. Psikolinguistik. Padang: IKIP Padang Press.

Moleong, Lexy. 2005. Metodologi Penelitian Kualitatif. Bandung: Remaja Rosdakarya Offset.

Nazir. 1988. Metode Penelitian. Jakarta: Ghalia Indonesia.

Tressyalina. 2007. Respon Verbal dan Nonverbal Anak Usia Prasekolah (Tesis). Padang: UNP. 